6 種類のフィルムのうちわれわれの実験では 3 種類のフ ィルムが特に良い結果が得られた。 また(2)現像処理につ いては現像温度および現像時間について検討したが, 一 部現像液を除いて同じような特性が見られた。現像液の 疲労度は $500 \mathrm{ft} 2$ 本/日.使用で, 2 週間以内ではほ之ん ど認められないが，画質の低下を防ぐためには 2 週間が 限度と思われる. (3)総合的評価においては同程度であっ たが，粒状性に多少の差があった。しかし，一部を除い て診断に使用しても影響はないと考えられる。

309. 各種新シネフィルムの特性とその検討

国立循環器病センタ一放射線診療部

○兼谷忠彦・中山一彦 若松孝司・坂下善治

今回われわれは，各種新シネフィルム CFS (K社), MI-CF (F社), RPI-C (A 社), PE-2711 (K社) の臨床 の場で使用していく中で，てれからのシネフィルムは高 感度で, ある程度ガンマの高いすのを用い, そのために は高温・短時間現像処理が有用となる。 また, 撮影装置 にオートアイリス等を組み込むことで体格の大きい被写 体, 複合斜位等露出不足になりやすい場合に対処しう る.

\section{0. シネフィルムの高温・短時間現像処理について} 国立循環器病センター

○中山一彦・兼谷忠彦・若松孝司

従来われわれは，X線シネフィルムの現像処理を，20 ${ }^{\circ} \mathrm{C}, 80$ 秒にて行なって来た. 今回高温・短時間現像処理 が臨床上有用性があるかどうか基礎的実験を行なった。

実験結果加 ，相対的汇高温・短時間現像処理する方 が, 感度的にはほぼ同じで, 高濃度部が押えられ，低濃 度部が少し濃度が上がり全体的に $\overline{\mathrm{G}}$ が低くなるととを示 した．また穴あきアクリルを用いた実験では，低濃度部 でのコントラストが高温・短時間現像処理することで改 善されるととがわかった. 粒状性む今回の実験では, 従 来のものと比較しても, 高温処理したからといって, 視 覚的に少化するととはなかった。 今後現像温度 $20^{\circ} \mathrm{C} に$ らわれることなる現像処理が行なえるといえる.

311. 国産シネフィルムについて

九州厚生年金病院

○西坂秀彦・岡部健吾・岡田寅彦

近藤正美 $\cdot$ 末弘正人

われわれは国産シネフィルム（フシ MI-CF）を，Kodak RAR 2496, CFS の 3 者で現像処理特性および臨床 写真での比較検討を行なった.

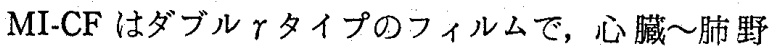

というコントラストの大きい部位に適し濃度補償フィル 夕を必要とせず簡便である．またGross Fog が $0.10 〜$ 0.11 と小さい. RAR 2496 や CFS と比較して感度は高 いが，粒状性はやや少る，現像処理において，特性值の 変動は小さいが，処理液内に溶解不純物による污濁が目 立つ.さらにフィルム走行時にシネカメラ内に粉末状の ヨゴレが付着しやすいが，総合して MI-CF は良行と判 断できる. Super RD-1 処理の場合 KLX 処理の時より 感度，粒状性は劣るが，特性值の変動は小さい。

\section{X線シネフィルム MI-CF の諸特性と臨床への応用} 関東崌信病院第 2 放射線科

○柳 能成・小林正敏 若愁 修・栗田道雄

〔目的〕従来よりX線シネフィルムは種々のむのが利 用されているが，われわれは今回フジX線シネフィルム MI-CF を使用する機会を得たので現在使用している $\mathrm{CFS}$ と比較検討したので報告する.

〔方法〕物理的特性の比較は CFS 之 MI-CF の両者 について現像処理を同一にした特性曲線, ウイナースペ クトル，RMS 粒状性等の比較を行ない検討を加えた結 果濃度特性では MI-CF は CFS 记対して gross Fog は, 0.11 とやや低く平均階調度 $\mathrm{G}$ はほとんど差がない，また 感度は濃度 0.9 で比較すると $52 \%$ 高い值を示した。

〔結果】今回使用する機会のあったX線シネフィルム MI-CF は物理的特性は CFS に比較して大差はないが, 感度が52\%良く患者被曝線量莪減の上からも評価でき る。

\section{X-レイシネフィルムの画質の検討（第 3 報）}

\section{三重大学医学部附属病院放射線部}

○中西 篤・山村和生

シネフィルムの特性のちがいによる，実際の画質への 影響と，造影目的の適合性と検討するため，冠動脈のそ クロトレースを行い, 冠動脈の背影心筋部濃度と血管コ ントラストの分布を調ベ，特性曲線との相関を検討した。 小児の先天性心疾患では, 右心系, 左心系の造影で造影 目的之観察性, こクロトレースの結果, および特性曲線 との相関について検討した.

結果は,フィルム特性による実際の画質の差を明瞭に すると共に，造影目的による要求されるフィルム特性の 違いをむ明瞭にした。

\section{座長集約}

とのセクションは，X線シネフィルムの選択と画質と の関係を明らかにしたものであると思わ机る，今日， $\mathrm{x}$ 線映画で用いられているシネフィルムの種類は，RAR 